Mykhailova Nelia, senior lecturer, Kyiv National University of Trade and Economics, 19, Kyoto str., Kyiv, 02156, Ukraine ORCID: 0000-0001-5401-203X, Researcher ID: B-8811-2019

\title{
MEANS OF ELECTRONIC EDUCATIONAL ENVIRONMENTS IN THE CONTEXT OF GLOBALIZATION
}

The article discusses the use of electronic educational environments and their role in the formation of foreign language broadcasting in the classroom. The use of new information technologies in education is one of means for preparing students in modern conditions, taking into account the tasks of the future. Modern Internet resources contribute to the formation of such communication skills as reading, writing, speaking, perception of a foreign language by ear. Electronic educational environments are a powerful motivator for students to learn a foreign language.

Keywords: electronic educational environments, distance education, case technologies, synchronous method, computer-aided education

Михайлова Неля. Засоби електронних навчальних середовищ у контексті глобалізації.

У статті обговорюються основні характеристики та використання електронних освітніх середовищ, а також їх роль у формуванні іншомовного мовлення на занятті. Наголошується, що використання нових інформаиійних технологій в освіті є одним із засобів підготовки студентів до сучасних умов з урахуванням завдань майбутнього. У статті також проаналізовано як комп'ютерні технології сприяють розв'язанню проблем у процесі навчання.

Особливу увагу приділено впровадженню інноваційних комп'ютерноорієнтованих технологій у прочесі вивчення іноземних мов.

Ключові слова: електронне освітнє середовище, дистанційне навчання, кейс-технології, синхронний метод, комп 'ютерне навчання

Relevance of research topic. Ukraine's integration into the international economic and information space necessitates the search for new approaches to the training of future foreign language specialists in accordance with international standards of linguistic competence. The use of electronic educational environments, 
Internet technologies in learning is becoming more relevant as the economic and social development of the country is gradually making the Internet a daily reality for students and teachers, and electronic educational environments are creating a new global environment. In this environment, the future generation should not only communicate but also build professional and personal relationships, position their interests and present themselves. And how well they succeed will depend on their personal wellbeing and professional success. That is why in recent years, great importance has been placed on informatization of the education system. Due to this, in the process of learning a foreign language, the purpose of education, apart from the development of foreign language communication competence, is the development of information competence. Today, a methodology for learning foreign languages with using the Internet resources is being developed. There are supporters of the idea of learning a foreign language only through the specified network, without traditional work with the textbook. However, most teachers prefer using the Internet in parallel with traditional learning tools, integrating it into the learning process. The current model of the educational process allows for the realization of new pedagogical tasks that determine the prospects of educational development, and significantly improve the effectiveness of learning in any field. These factors determine the relevance of the research topic.

Formulation of the problem. The growth of information flow in a significant expansion of business, professional and cultural ties of Ukraine with EU countries requires a graduate with a level of foreign language proficiency of at least B2 (an independent user), which meets modern European standards (Dudeney G., 2007). This situation necessitates the development of new approaches to teaching a foreign language as a compulsory discipline in a higher education institution, the introduction of innovative learning technologies and techniques in the educational process, which will contribute to the formation of skills and competencies for vocational orientation (Allur E., 2014).

Analysis of recent researches and publications. Problems with the use of Internet technologies in the teaching of foreign languages were studied by such scientists as E.G. Azimov, P.G. Asoyants, T.I. Koval, O.M. Kuzhel, V.M. Kukharenko, N.I. Mulina, E.L. Nosenko, P.I. Serdiukov, V.P. Sviridiuk, O.B. Tarnapolsky, G.S. Chekal, N.M. Chemeris, T. Upton, P. Bracamonte, K.H. Briucher, M.P. Collins, P. Dankel, K. Richardvords, M. Simonson, A. Thompson et al. According to researchers, in recent years the use of computers has become an integral part of the foreign language learning process, while the advent of the Internet has dramatically changed the process. The enormous amount of information and the speed of work with them make it possible to transform language education into a qualitatively new learning. However, the use of Internet technologies in foreign language classes as a prerequisite for organizing students' academic autonomy remains underdeveloped.

Presenting main material. Analyzing and summarizing the results of recent scientific studies suggests that scientists are identifying certain areas in which 
computer-aided technologies are widely used because they have advantages over human capabilities in terms of their technical characteristics: communication (electronic communication is divided into synchronous and asynchronous); creation of training exercises (all types of speech activity are trained and refined through computer repetition); creation of test exercises (speed and efficiency of conducting and checking of tests helps the teacher to determine the students' knowledge level).

The widespread use of Internet technologies over the last decade has led to the introduction of a new form of education - distance education. The relevance of distance learning is explained by the availability of education, and therefore the opportunity to increase their competitiveness in the educational market. Distance learning attracted attention to one of the most important problems in learning maintaining the quality of education. The learning process is accomplished through computer-aided technology of distance learning, which are conditionally divided into 3 groups:

1. Case technologies are the learning technologies with the help of which a student sends a package of study materials or a so-called self-study case. Teacher performs the student's fulfillment of tasks in-class (classroom, consultations) or an extramural (via email) form.

2. Television and satellite technology is the learning technology by which it is used lectures or seminars are broadcast simultaneously to several audiences.

3. Network technologies - Internet technologies that provide the opportunity territorially distant students with educational and methodological material, to carry out «virtual communication» between the teacher and students, set the individual pace of learning and development of educational material.

In the process of distance learning an important aspect is the communication between the participants of the educational process. Computer-aided technologies used in foreign learning languages, can be roughly divided into 2 groups: synchronous and asynchronous means of communication. As a rule, synchronous communications allow the teacher to communicate with the student in the mode of real time using the Internet. Asynchronous Communication Tools - these are Internet technologies which allow sharing information with time delay. About synchronous and asynchronous remote control techniques trainings are spoken from the point of view of various methods' application for increase of the teaching efficiency. The synchronous method of distance learning involves the active interaction of the teacher and the student. In asynchronous distance learning, self-study comes to the fore, individual pace of study. Most experts have recently come to the conclusion that the greatest effectiveness in distance learning can be achieved by using mixed methods of distance learning. There is a term «mixed distance learning», which assumes that the training program is built as an element of synchronous methodology distance learning and elements of asynchronous distance learning methodology. Synchronized methods of computerbased communication are being actively implemented in the process of teaching 
a foreign language in order to empower students to study it through real-time communication. The main synchronous means of communication include text chats, audio and video conferencing.

Chat technology is a way of organizing ground-based distance learning using network technology to create a virtual learning environment for communication of two or more partners in real-time communication. Teaching of students in a synchronous mode that creates a virtual learning environment helps to develop of reading and writing skills in the form of unprepared dialogues. Such communication can be created through chat technology, and one of the tools is a chatroom.

Videoconferencing is one of the priority areas of contemporary education development, as it contributes to the globalization of research, and it is expanding boundaries of scientific knowledge, promotes interactive communication and individualized approach to study. O.M. Samoilenko distinguishes the following types of videoconferences (Samoilenko O.M., 2008): 1. Personal or individual - direct communication of two people (teacher and student) from a video call. Such conferences are most often used during distance learning and are intended for mutual discussion of problematic questions and unclear issues on the topic. The undeniable advantage of personal conferences is the «whiteboard» through which you can not only view and edit, but also create text and image files, being in the main conference window.

The following equipment is required for individual video conferencing: personal computer with audio and video support encoder, camcorder, microphone, high-speed modem, and network connection or ISDN line.

1. Group Communication of medium and large groups of participants with one another with the help of video-connection. Group conferences allow to have discussions, seminars, to discuss specific problems in real time, even though participants are located hundreds of kilometers apart. For group video conferencing the following equipment is required: view screen, ISDN connection, and specialized equipment.

2. Studios Communication of the lecturer with the audience via video communication.

Next method is scaffolding, the essence of which is necessary to create working groups consisting of two people: a beginner student and a language student expert. Working groups are invited to work out certain tasks (both lexical and grammatical) within a specific conversation topic. Synchronous communication facilitates the development of fluency and mastering grammar correctly. This view is confirmed by linguists, emphasizing that grammatical accuracy and the growth of the student's lexical stock should be equally important to him in the process of mastering a foreign language, in other words, to develop a student's language competence. The help of language expert should be provided to the student instantly when correcting various errors as focusing on form while correcting a mistake in a communicative context 
process is of great importance for mastering his language. This is how students collaborating with language experts, solve linguistic problems. For efficiency of scaffolding appropriate training should be conducted, thereby enhancing the potential contribution of the corrective feedback through computer-assisted communication. Use of native language as a mediating tool can be necessary for cognitive tasks while foreign language is used as a means of communication. Along with traditional learning tools, podcasting technology has a special place. It has a number of advantages: it allows you to choose the theme and style of your choice; create your own podcasts independently; download authentic podcasts automatically using special programs; listen to downloaded files at a convenient time and the required number of times; develop skills in understanding authentic English texts. The main prerequisite of learning is the choice of authentic texts, where the degree of the texts complexity depends on the level of language proficiency. Use of authentic texts in teaching of elementary or intermediate students is compulsive because it allows you to become familiar with lexical material and grammatical constructions.

Conclusion. Computer-aided educational technologies have significant potential for improvement of mastering all kinds of speech activity; intensive use of the technology increases time and motivation factors of language learning; the latest technologies expand the educational space, opening access to the educational material and communication beyond the reach of the teaching audience. Computer technology has become the most powerful and affordable means of a foreign language learning in recent decades.

\section{REFERENCES}

1. Allur E., Heras-Saizarbitoria I., \& Casadesus M. (2014). Internationalization of ISO 9001: A longitudinal survey. Industrial Management \& Data Systems, 114(6), 872-885. Retrieved from: http://www.emeraldinsight.com/doi/full/10.1108/IMDS-012014-0013

2. Dodge B. Some Thoughts About Web Quests [online] / B. Dodge. - Retrieved from: webquest.sdsu.edu/about_webquests.html

3. Dudeney G., Hockly N. (2007). How to teach English with technology / Series editor: Jeremy Harmer. - Harlow: Pearson Education Limited. - 192 p.

4. Samoilenko O.M. (2008). Videoconferenentsii v systemi dystantsiinoi osvity / O.M. Samoilenko //Informatsiini tekhnolohii i zasoby navchannia. - № 2. Retrieved from: https://oai.org.ua/index.php/itlt/article/view/137/123

5. «Shcho take Smart Education?» - Rozumna osvita dlya rozumnoho suspilstva (2017) [online]. Retrieved from: http://smarteducatoin.blogspot.com/2016/ 06/smart-education.html?m=1 